\title{
Hepatitis B Virus Antibody Measurement
}

National Cancer Institute

\section{Source}

National Cancer Institute. Hepatitis B Virus Antibody Measurement. NCI Thesaurus.

Code C125944.

The determination of the amount of hepatitis B virus antibody present in a sample. 